\title{
RISK-RETURN AND DIFFERENCE OF IPE WOOD PRICE IN PARÁ AND SÃO PAULO MARKETS
}

\author{
Humberto Figueira Barbosa ${ }^{1}$, Lyvia Julienne Sousa Rego ${ }^{1}$, Márcio Elly Piero ${ }^{1}$, Rommel Noce ${ }^{1}$, Juliana Mendes de \\ Oliveira $^{1}$, João Ricardo Vasconcellos Gama ${ }^{1}$
}

*Autor para correspondência: humberto_figueira@hotmail.com

ABSTRACT: This study estimated the relation risk-return and the trend of the price difference among the markets of consumers of Ipê amarelo (Tabebuia serratifolia) sawn wood in the State of Pará and the cities of Baurú, Campinas, and Sorocaba,. It was considered as indicative of risk the Coefficient of Variation (CV), and as indicative of return the Rate of Geometric Growth (RGG) of the price series that was also used to estimate the trend of the price difference among the markets. It was noted that the risk-return relationship is coherent in all markets, and the city of Sorocaba stands out with the greatest estimative in both risk and return, and presents increase trend of the price difference among State of Pará market, which presented a temporal deficit in the price increase compared to other markets analyzed.

Key words: forest economy, attractiveness, private investment

\section{RISCO RETORNO E DIFERENÇA DE PREÇO DO IPÊ NOS MERCADOS DO PARÁ E INTERIOR DE SÃO PAULO EM 2007}

RESUMO: Conduziu-se este trabalho, com o objetivo de estimar a relação risco e retorno e a tendência da diferença de preços entre o mercado do Estado do Pará e das cidades de Baurú, Campinas e Sorocaba consumidores de pranchas de madeira do Ipê amarelo (Tabebuia serratifolia). Admitiu-se, como indicativo de risco, o coeficiente de variação (CV) e como retorno a taxa geométrica de crescimento (RGG) das séries de preço que também foi empregada para estimar a tendência da diferença de preço entre os mercados. Observou-se que a relação de risco retorno é coerente em todos os mercados, sendo que o da cidade de Sorocaba se destaca com as maiores estimativas tanto de risco como retorno, além de apresentar a maior tendência de aumento de diferença de preço em relação ao mercado do estado do Pará que apresentou um déficit temporal no aumento de preço em relação aos demais mercados analisados.

Palavras-chave: Equilibrium moisture content, modeling, temperature, relative humidity of air.

\section{INTRODUCTION}

The integration of the economy intensifies the dynamics of the strategies and productive activities that unfold in political, social and economic aspects. As a result, there is a greater concern with risk and uncertainty of markets (COELHO JUNIOR et al., 2008).

The State of Pará is the largest wood pole of the Amazon region, accounting for $45 \%$ of the volume of processed wood in the region. Most of the production of the State supplies the Brazilian domestic market, especially the South and Southeast regions, and the state of São Paulo stands out as the largest consumer market of wood from the Amazon region (LENTINNI et al., 2005).

Sawn wood, representing $43,62 \%$, continues leading exports, after comes the segment of wood floors with 38,12\% (ASSOCIAÇÃO DAS INDÚSTRIAS EXPORTADORAS DE MADEIRA DO ESTADO DO PARÁ - AIMEX, 2010). In Brazil, the Southeast region stands out as the major consumer of wood from the State of Pará (PAIVA, 2009).

The analysis of price behavior and risk contributes to the quality of decision-making of economic agents and visualization of future scenery (BURATTO, 2005). Variation tendency analysis of the price refers to the relative price change of a product in a market to a price variation of the same product in another market (BARROS et al., 1987 apud MARGARIDO et al., 2001).

This study expects to collaborate to the understanding and rationalization of decision-making of forest management in the Amazon region, through the understanding of the market, helping the development of the productive chain. In addition to contribute to the development of geared policies preservation of forest resources by indicate the attractiveness of Tabebuia serratifolia sawn wood to the private capital.

This work had as objective to estimate the riskreturn relation and the trend of the price difference among

${ }^{1}$ Universidade Federal do Oeste do Pará - Santarém, Pará, Brasil 
State of Pará market and the cities Baurú, Campinas and Sorocaba (State of São Paulo): Ipê amarelo (Tabebuia serratifolia) sawn wood consumers.

\section{MATERIALS AND METHODS}

The data base used in the analysis and estimative that composes this study is a series of sales prices of Ipê's sawn wood, available at Centro de Estudos Avançados em Economia Aplicada - CEPEA(2010) - covering the year 2007.

The data series were expressed graphically to show the behavior of prices of the Ipê's sawn wood. The RGG (Rate of Geometric Growth) and CV (Coefficient of Variation) were calculated for representative product series.

Through the elaboration of the dispersion graphics, it was described the risk-return relationship of the marketed product in different markets. It was admitted the Rate of Geometric Growth (RGG) as a reference of the return expectation and the Coefficient of Variation (CV) as a reference of the associated risk. This procedure was already employed in the forest area, allowing to verify that the sawn wood of different tropical species have coherent risk-return relationship (NOCE et al., 2010) and that the only wood products that presented favorable relation to fund raising in the decades of 1970, 1980 and 1990, were the sawn and planed wood (NOCE et al., 2005). This methodology was used in other sectors such as agriculture (MOTA et al., 2005), agribusiness by Montoya et al. (1996) and economy by Sousa (2003).

The CV was obtained through the quotient between the standard deviation and the arithmetic mean of the series. The use of the $\mathrm{CV}$ is recommended as a dispersion measure among series of different distributions (SPIEGEL, 1985).

$C V=\left(\frac{s}{\bar{m}}\right) 100$

Where:

$C V=$ coefficient variation;

$\mathrm{s}=$ standard deviation;

$\bar{m}=$ arithmetic mean.

RGG's were calculated using the software E-Views 5.0, statistically determined by linear regression of tendency represented by the following expression:

$\log Y=a+b T$

Cerne, Lavras, v. 20, n. 1, p. 69-72, jan./mar. 2014
Where:

$Y=$ corrected price in $R \$$;

$a=$ constant of the regression;

$b=$ coefficient of the regression; and

$T=$ tendency.

For values of "b" significantly different from zero, the Geometric Rate of Growth was calculated by the formula: Ant Logb $=1+T G C / 100$

$T G C=($ AntLogb-1)x100

The Rate of Geometric Growth (RGG) expresses the growth of the series, in percentage, per period of time analysis. Levels of significance of the estimated parameter "b", appraised according to " $\mathrm{t}$ " test, superior to $10 \%$, increase the probability of error in affirming that RGG is statistically different from zero. Therefore, only estimated values significant at $5 \%$ of probability, were considered.

It was generated series by series of the difference prices of Pará and the markets in the inland of the State of São Paulo to estimate the tendency of the price difference among them. This was only possible through the RGG.

\section{RESULTS AND DISCUSSION}

\subsection{Risk-return relationship}

The four markets analyzed showed a risk-return relationship coherent for the practiced Ipê's sawn wood price. The positive values observed for the return and risk configure the markets of the cities of Sorocaba, Campinas, Baurú and the State of Pará as attractive to private investment (FIGURE 1).

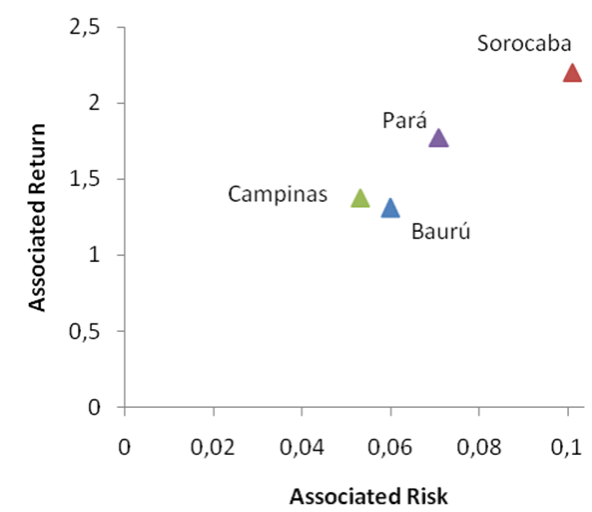

Figure 1- Risk-return relationship of Ipê's sawn wood among the markets of the State of Pará, Sorocaba, Campinas and Baurú, year 2007.

Figura 1 - Relação Risco e Retorno da prancha de Ipê entre os mercados do Pará, Sorocaba, Campinas e Baurú, ano 2007. 
It was noted that the market of the city of Sorocaba presented the greatest associated return and also the highest risk level, showing that it is the more attractive market to investors willing to risk. The market of the city of Campinas overcame the market of Baurú in attractiveness, because presented a superior return and inferior level risk, although the results were relatively close (Table1).

Table 1 - Estimated risk and return for each market, considering the time horizon from January to December 2007.

Tabela 1 - Risco e retorno estimado para cada mercado, considerando o horizonte temporal de janeiro a dezembro de 2007.

\begin{tabular}{ccc}
\hline MARKETS & RISK $($ RGG $)$ & RETURN $(\mathrm{CV})$ \\
\hline Campinas & 0,05 & 1,38 \\
Baurú & 0,06 & 1,31 \\
Pará & 0,07 & 1,77 \\
Sorocaba & 0,10 & 2,20 \\
\hline
\end{tabular}

The estimated risk increases proportionally to the return for the markets of the city of Campinas, State of Pará and the city of Sorocaba, successively. The exception was the market of the city of Baurú (Figure 1 and Table 1).

\subsection{Price difference trend}

The State of Pará has presented the lowest prices, which can be attributed to the fact that the wood is extracted in the region, including a smaller number of middlemen in the trading process. It was noted that from the month of January to July the prices remain stable, but from the month of August to December the prices increased (Figure 2). The supply of wood is influenced by the period of wood extract management that corresponds to the dry period in the Amazon region and, eventually, possible delays in the approval of management plans, given the behavior of prices.

The markets of the towns of Baurú and Campinas presented similar behaviors. From June, prices stabilized, showing slight fluctuations. On the market of Sorocaba, there has been an evolution in prices from February until April, which corresponds to the period of increased rainfall in the Amazon region and retraction of the offer. From the month of April, prices were more stable until December. It was noted that in the markets of the towns in the inland of São Paulo rising prices coincides with the rainy season, while in the State of Pará the elevation is only observed in the second semester. This fact can be associated with the logistics difficulty that is imposed on the Amazon region with the rainy season, which substantially restricts the supply of the product in other markets. The consumption concentrates on these markets that showed to be more sensitive to fluctuations in supply (Figure 2).

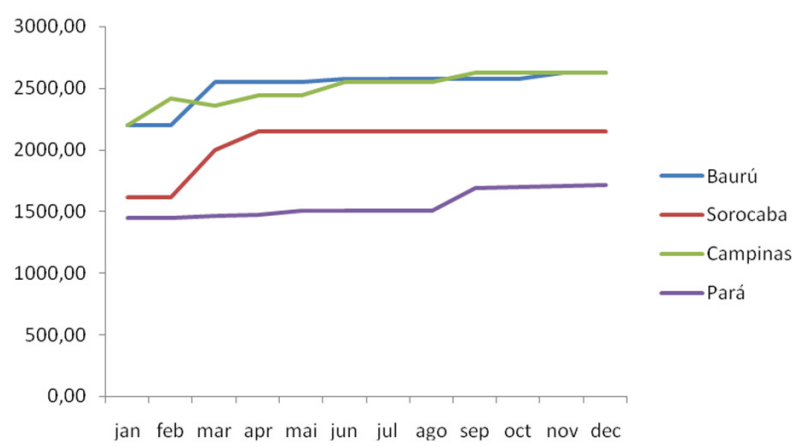

Figure 2 - Price behavior of Ipê's sawn wood in the markets of the State of Pará and the cities of Campinas, Sorocaba and Baurú, year 2007.

Figura 2 - Comportamento dos preços de pranchas de Ipê nos mercados do estado do Pará e das cidades de Sorocaba, Campinas e Baurú, ano 2007.

The markets of the towns of Baurú and Campinas had the largest price difference compared to the price practiced in the State of Pará with 61,2 and 60,5\%, respectively. It was observed a trend that the difference increases over the year, being 0,59 and $0,71 \%$ for the markets of Baurú and Campinas, respectively (Table 2).

Table 2 - Average difference and transmission trend of price of Ipểs sawn wood

Tabela 2 - Diferença média e tendência da transmissão de preços da prancha de Ipê

\begin{tabular}{ccccc}
\hline CITIES & $\begin{array}{c}\text { AVERAGE } \\
\text { PRICE }\end{array}$ & $\begin{array}{c}\text { AVERAGE } \\
\text { DIFFERENCE } \\
\text { OF PRICE }\end{array}$ & $(\%)$ & $\begin{array}{c}\text { TRANSMIS- } \\
\text { SION TREND } \\
\text { OF PRICE }\end{array}$ \\
\hline Baurú & 2513,43 & 954,45 & 61,2 & 0,59 \\
Sorocaba & 2048,33 & 489,36 & 31,4 & 5,93 \\
Campinas & 2502,04 & 943,07 & 60,5 & 0,71 \\
\hline
\end{tabular}

The market of the city of Sorocaba showed to be the one with the smallest average price difference in relation to the market of the State of Pará. However, the Sorocaba's market presented the strongest growth trend of the price difference among the markets, being of 5,93\% per month during the year 2007. This is coherent with the high return rate noted. The price of Ipê's sawn wood practiced on the market of the city of Sorocaba tends to approach to the values observed in the markets of the towns of Baurú and Campinas throughout the year (Table 2).

Cerne, Lavras, v. 20, n. 1, p. 69-72, jan./mar. 2014 


\section{CONCLUSIONS}

In the conditions that this study was accomplished, it could be concluded that:

All markets analyzed present coherent risk return ratio, that favors the entry of private initiatives in the activity of production and marketing of Ipê's sawn wood in the State of Pará and in the cities of Campinas, Sorocaba and Baurú;

The market of the city of Sorocaba is especially attractive to investors risk-prone, since presented higher estimate for both risk and return;

Throughout the year the price of Ipê's sawn wood in Sorocaba's market tends to approach the prices practiced in Baurú and Campinas markets;

\section{REFERENCES}

\section{ASSOCIAÇÃO DAS INDÚSTRIAS}

EXPORTADORAS DE MADEIRA DO ESTADO DO

PARÁ. Pará exporta mais produtos beneficiados.

Disponível em: <http://www.aimex.com.br/>. Acesso em: 10 dez. 2010.

BURATTO, M. V. Construção e avaliação de um modelo de simulação de Monte Carlo para analisar a capacidade de pagamento das empresas em financiamentos de longo prazo. 2005. 141 p. Dissertação (Mestrado em contabilidade e Finanças) - Universidade Federal do Rio Grande do Sul, Porto Alegre, 2005.

\section{CENTRO DE ESTUDOS AVANÇADOS EM ECONOMIA APLICADA. Informativo CEPEA setor florestal. Disponível em: <http://cepea.esalq.usp.br/>. Acesso em: 15 nov. 2010.}

COELHO JUNIOR, L. M.; REZENDE, J. L. P.; OLIVEIRA, A. D.; COIMBRA, L. A. B.; SOUZA, A. N. Análise de investimento de um sistema agroflorestal sob situação de risco. Cerne, Lavras, v. 14, n. 4, p. 368-378, 2008.

LENTINNI, M.; PEREIRA, D.; CALENTANO, D.; PEREIRA, R. Fatos florestais da Amazônia. Belém: RL/2 Comunicação e Design, 2005. 67 p.

MARGARIDO, M. A.; TUROLLA, F. A.;

Cerne, Lavras, v. 20, n. 1, p. 69-72, jan./mar. 2014
FERNANDES, J. M. Análise da elasticidade de transmissão de preços no mercado internacional de soja. Pesquisa \& Debate, São Paulo, v. 12, n. 2, p. 32-40, 2001.

MONTOYA, M. A.; MARTINS, R. S.; MARQUE, P. $\mathrm{V}$. Tendência da concentração no sistema agroindustrial brasileiro. Teoria e Evidência Econômica, Passo Fundo, v. 4, n. 7/8, p. 7-22, 1996.

MOTA, J. H.; NOCE, R.; YURI, J. E.; RESENDE, G. M.; SOUZA, R. J. Análise da evolução da produção e relação risco-retorno para a cultura do alho, no Brasil e regiões: 1991 a 2000. Horticultura Brasileira, Brasília, v. 23 , n. 2, p. 238-241, abr./jun. 2005.

NOCE, R.; SILVA, M. L.; MENDES, L. M.; SOUZA, A. L.; REZENDE, J. L. P.; CARVALHO, R. M. M. A.; CANTO, J. L.; OLIVEIRA, J. M. Risk-return of native species sawn wood in the state of Pará, Brazil 20032007. Cerne, Lavras, v. 16, n. 2, p. 199-207, 2010.

NOCE, R.; SILVA, M. L.; SOARES, T. S.; CARVALHO, R. M. M. A. Análise de risco e retorno do setor florestal: produtos da madeira. Revista Árvore, Viçosa, v. 29, n. 1, p. 77-84, jan./fev. 2005.

PAIVA, C. V. Análise da produção madeireira do estado do Pará. 2009. 18 f. Monografia (Graduação em Engenharia Florestal) - Universidade Federal Rural do Rio de Janeiro, Rio de Janeiro, 2009.

SOUSA, N. J. Abertura comercial e crescimento dos estados brasileiros, 1991/2000. Teoria e Evidência Econômica, Passo Fundo, v. 11, n. 21, p. 41-61, 2003.

SPIEGEL, M. R. Estatística. São Paulo: McGraw-Hill, 1985. 454 p.

Received: April 20, 2011; accepted: July 03, 2013. 